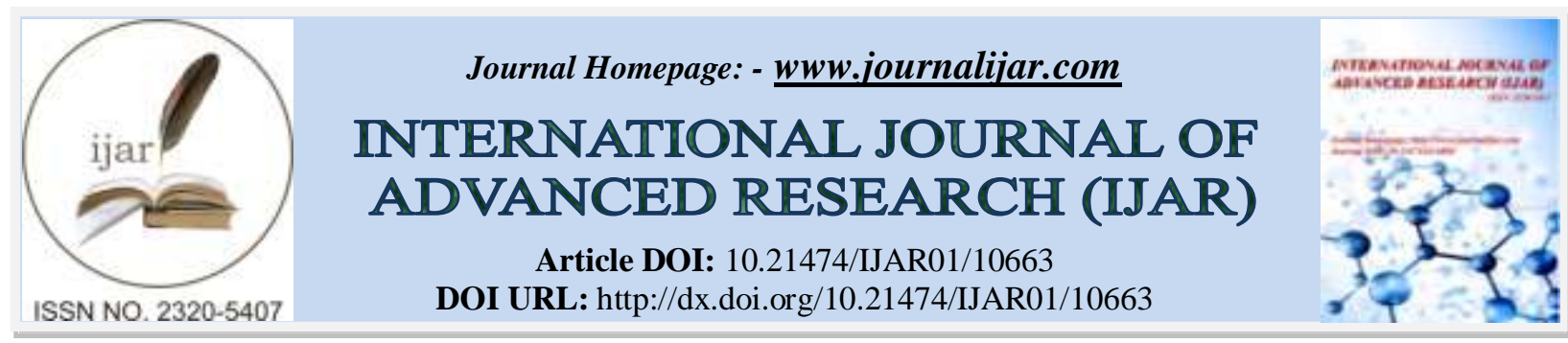

RESEARCH ARTICLE

\title{
STUDY OF THE GENETIC ANALYSIS OF SOME SELECTED OKRA GENOTYPES
}

\section{A.T.M. Hamim Ashraf ${ }^{1}$, Dr. M. Mizanur Rahman², Dr. M. Mofazzal Hossain ${ }^{2}$ and Umakanta Sarker $^{3}$}

1. Upazila Agriculture Officer, Fulbari, Dinajpur, Department of Agriculture Extension, Ministry of Agriculture, Govt. of the people's republic of Bangladesh.

2. Department of Horticulture, Bangabandhu Sheikh MujiburRahman Agricultural University, Gazipur, Bangladesh.

3. Department of Genetics and Plant Breeding, Bangabandhu Sheikh MujiburRahman Agricultural University, Gazipur, Bangladesh.

\section{Manuscript Info}

Manuscript History

Received: 15 January 2020

Final Accepted: 17 February 2020

Published: March 2020

Key words:-

Abelmoschusesculentus, Genetic

Advance, Heritability, Variability

\section{Abstract}

An experiment was conducted at the experimental farm, Department of Horticulture, Bangabandhu Sheikh MujiburRahman Agricultural University, Gazipur with an aim to study the genetic variability of selected okra genotypes. The study was laid out in Complete Randomized Block Design from March 2008 to July 2008. The studied characters were studied to find out the genetic variability, heritability and genetic advance, and correlation coefficient. The genotypes varied significantly $(\mathrm{p}<0.01)$ for all of the characters studied. The phenotypic and genotypic variance was highest for plant height (252.54 and 422.78) followed by fruits per plant (6.33 and 7.19) and yield (6.06 and 7.17). The estimate of heritability in broad sense ranged from $28.60 \%$ for fruit weight to $87.96 \%$ for fruits per plant. The heritability estimate in broad sense was high $(>60 \%)$ for branches per plant $(63.58 \%)$, picking duration (70.04\%), days to first fruit harvest (71.46\%), fruits per plant $(87.96 \%)$ and fruit yield $(84.55 \%)$. The genetic advance (in $\%$ of mean) ranged between $5.00 \%$ for days to first flowering to $52.08 \%$ for yield ( $t / h a)$. The highest $(\geq 20 \%)$ genetic advance was observed for branches per plant, days to first fruit harvest, fruits per plant and yield $(\mathrm{t} / \mathrm{ha})$. The high degree of genotypic and phenotypic coefficients of variation were recorded in number of primary branches per plant (26.10\% and $20.81 \%)$, fruits per plant $(26.26 \%$ and $24.63 \%)$ and fruit yield (29.90\% and $27.49 \%$ ), respectively. This experiment aimed to evaluate the okra genotypes for genetic variability analysis with a view to providing information onthe selection of high yielding.

Copy Right, IJAR, 2020,. All rights reserved.

\section{Introduction:-}

Okra (Abelmoschusesculentus L. Moench) is commonly called okra or lady's finger and one of the most popular vegetable in tropical and subtropical regions (Patil et al., 2015) of the world. It is considered a staple food for the population in several countries in the world due to high socioeconomic and nutritional relevance (Hughes, 2009; Gemedeet al., 2015; Kumar et al., 2017a). The fruits of Okra and its seeds are edible, and immature fruits are rich in dietary fibre, carbohydrates, vitamins, minerals, and antioxidant substances (Purkaitet al., 2016; Petropoulos, et al., 
2018). For those populations that include it as part of their diet, it is also an important source of protein, minerals, vitamins and roughage (Rashid, 1999). The okra seeds are rich in high-quality proteins (20-24\%), edible oil (13$22 \%$ ) and also have of two important amino acids namely lysine and tryptophan (Hughes, 2009). Okra seeds also contain some amount of caffeine that can use as a free substitute for coffee. The annual vegetable production is not uniformly distributed among the seasons in Bangladesh. Since okra is photo insensitive, it has got great importance to produce in the leanummer season (Anon., 1993). The yield of okra in Bangladesh is low particularly due to lack of high yielding varieties.Poor quality okra genotype seed use is one of the most important causes of poor yield of okra in Bangladesh. High yield potential genotype with good characteristics is the basis of successful crop production and is important for increasing the productivity. So, in case of genotypes yield potential must be considered for commercial production. A good knowledge of genetic resources might also help in identifying desirable cultivars for commercial cultivation. Lack of high yielding, disease and pest tolerant variety is the main constraints toward its production. Among the cultivars, a wide range of genetic variability exists in this crop that can be exploited for its improvement. It is the touchstone to a horticulturist or a breeder to develop high yielding varieties through selection from the existing genotypes. Hence, information on variability in respect of yield and its contributing characters required to be properly assessed for its improvement.By using valid information about the correlation and genetic variability of traits of interest knowing full well that improvement in any crop is dependent on the amount of genetic variability in the population. To obtaining capable crosses, phenotypically varied genotypes most probably of diverse source are often regarded as more effective (Duzyaman and Vural, 2002). To increase the yield potential of a crop plant, an understanding of the mode of inheritance of the yield components, the correlations among them and the relationship between the components and yield is necessary for a better selection of breeding procedures (Ahmad et al., 2003 and Khodambashi et al., 2012). In the assessment of genetic variability for the particular character, co-efficient of variation is useful. Correlation coefficient analysis is useful in the selection of several traits simultaneously influencing yield (Menkir, 2008). Path analysis can effectively use for better insight into cause and effect relationship between different pairs of traits (Jayasudha, 2010).The association among traits may be measured depending on the types of studied materials and the kind of experimental design used by genotypic and/or phenotypic coefficients of correlation (Sadek et al., 2006).Keeping in view, the present investigation was done to ascertain the nature and magnitude of genetic variability of yield and its components to identify the horticulturally superior genotypes of okra.

\section{Materials and Methods:-}

\section{Plant material, experimental design and growing condition}

At the experimental farm of the Bangabandhu Sheikh MujiburRahman Agricultural University (BSMRAU), Salna, Gazipur, Bangladesh this experiment was conducted from March 2008 to July 2008. The location of the site is $24.09^{\circ} \mathrm{N}$ latitude and $90.26^{\circ} \mathrm{E}$ longitude with an elevation of $8.2 \mathrm{~m}$ from sea level (Anonymous, 1989). The climate of the experimental site is characterized by heavy rainfall from May to September and scanty during the rest of the year. The soil was sandy loam in texture and belongs to the silty clay loam of shallow red-brown terrace under the Salna series having a $\mathrm{pH}$ of 6.3. Fourteen diverse genotypes of okra were used in this experiment. The name of the genotypes with their country of origin and name of organization or company is presented in Table 1. The experiment was carried out in Randomized Complete Block Design (RCBD) with three replications. The unit plot size was 4.0 $\mathrm{m}$ X $1.5 \mathrm{~m}$. Each of the unit plots was separated by $0.50 \mathrm{~m}$ and block to block were $1.0 \mathrm{~m}$ apart. Every unit plot had 3 rows with 10 plants of each row. So, the total number of plants per plot was 30 .

Table 1:- List of okra varieties.

\begin{tabular}{|l|l|l|}
\hline Variety & Origin/Country & Company/Organization \\
\hline Anamika & India & Chad seed company \\
\hline Antara & India & Rajib seed store \\
\hline ArkaAnamika & India & United seed store \\
\hline BARI Dherosh 1 & Bangladesh & BARI, Gazipur \\
\hline Ghinuk & Bangladesh & United seed store \\
\hline Green Boy & Bangladesh & United seed store \\
\hline Green Glory & Bangladesh & East west seed ltd. \\
\hline IPSA Okra & Bangladesh & BSMRAU, Gazipur \\
\hline Jhalok & Bangladesh & United seed store \\
\hline Kanchan & Bangladesh & United seed store \\
\hline
\end{tabular}




\begin{tabular}{|l|l|l|}
\hline Liza-151 & India & Hi seed company \\
\hline Rupaly & Bangladesh & United seed store \\
\hline Seminis & USA & Hi seed company \\
\hline Sobuj Bangla & Bangladesh & United seed store \\
\hline
\end{tabular}

To get a good tilth, the field was plowed and cross-plowed several times. By the addition of well-decomposed cowdung at the rate of $5 \mathrm{t} / \mathrm{ha}$, weeds and stubbles were removed and the land was finally prepared. The plots were raised $10 \mathrm{~cm}$ from the soil surface to keeping the drain around the plot. Manure and fertilizer doses and their methods of application were applied in the experiment field as per recommend by (Rashid, 1999) are show in Table 2.

Table 2:- Manure and fertilizer doses with their application methods.

\begin{tabular}{|c|c|c|c|c|}
\hline \multirow[t]{2}{*}{ Manure/ fertilizer } & \multirow{2}{*}{$\begin{array}{l}\text { Total } \\
\text { Amount } \\
\text { (kg/ha) }\end{array}$} & \multirow{2}{*}{$\begin{array}{l}\text { Basal dose } \\
(\mathrm{kg} / \mathrm{ha})\end{array}$} & \multicolumn{2}{|l|}{ Top dressing (kg/ha) } \\
\hline & & & $\begin{array}{l}\text { First } \\
\text { (25 days after sowing) }\end{array}$ & $\begin{array}{l}\text { Second } \\
\text { (40 days after sowing) }\end{array}$ \\
\hline Cowdung & 5000 & Entire amount & - & - \\
\hline Urea & 150 & - & 75 & 75 \\
\hline TSP & 120 & Entire amount & - & - \\
\hline MP & 110 & Entire amount & - & - \\
\hline
\end{tabular}

The seeds were sown in rows of the raised bed. Row to row and plant to plant spacing was maintained $50 \mathrm{~cm}$ and 40 $\mathrm{cm}$, respectively. In each pit, two or three seeds were sown. Then by hand the seeds were covered with fine soil. Throughout the cropping season, necessary intercultural operations were done for the proper growth and development of the plants. To grow in each pit, five to 6 days after germination only one healthy seedling was kept and other seedlings were removed. After the germination of seedling up to fruiting, irrigation was given as and when required. At the time of heavy rain, stagnant water was effectively drained out. Weeding and mulching were done at regular intervals to break the soil crust and to keep the plots free from weeds. For controlling borer insect, malathion@ $0.2 \mathrm{ml} / \mathrm{L}$ was sprayed thrice in an interval of 7 days started as soon as the pest appeared. Admare @ $0.5 \mathrm{ml} / \mathrm{L}$ was sprayed three times in an interval of 7 days when hopper and Jassid found in the experiment field. From each plot, ten plants were selected at random for collecting data. Characters studied regarding growth attributes were plant height, branches per plant, while regarding yield attributes, days to first flowering, days to first fruit harvest, fruit length, fruit diameter, fruit weight, fruits per plant, picking duration, yield per plant, yield and virus infestation.

\section{Statistical Analysis:}

The analysis of variance as suggested by Panse and Sukhatme, 1985. The significance was tested against the ' $F$ ' value by referring to the statistical and mathematical tables given by Snedecor and Cochran, 1967. Phenotypic and genotypic variances were computed as per the formula of Johnson et al., 1955. Phenotypic and genotypic coefficients of variations (PCV and GCV) were computed following Burton, 1953 and expressed in per cent. The estimates of PCV and GCV were categorized as suggested by Sivasubramaniam and MadhavaMenon, 1973. Heritability in broad sense (h2) was estimated based on the formula proposed by Lush, 1940 and expressed in per cent. The range of heritability was categorized as follows genetic advance and was range of genetic advance as per cent of mean worked out based on the formula suggested by Johnson et al., 1955.

\section{Results and Discussion:-}

Estimation of analysis of variance and genetic parameters of different okra genotypes The ranges of mean values revealed sufficient variation for all the traits under study. In the material under study, maximum range of variability (Table 3) was observed for plant height $(123.2-174.5 \mathrm{~cm})$ followed by fruits per plant $(6.70-15.27)$ and yield (6.04$13.73 \mathrm{t} / \mathrm{ha})$. 
For all the characters under study, phenotypic variances were higher than the corresponding genotypic variances (Table 3).The phenotypic variance was highest for plant height (422.78) followed by fruits per plant (7.19) and yield (7.17). The phenotypic variance was lowest for branches per plant (0.26) followed by fruit diameter (1.09) and fruit length (2.02). The genotypic variance ranged from 0.62 (branches per plant) to 252.54 (Plant height). Similar result was reported by Mehta et al. (2006); Akotkaret al. (2010) for fruit plant height and number of tender fruit per plants. This result is in agreement with the result of Ibrahimet al. (2013) who reported that phenotypic variances were higher than the corresponding genotypic variances indicating predominance of environmental effects on the expression of these studied characters. This study result showed that the traits exhibited phenotypic variances higher than their respective genotypic variances thus revealing the great significant influence of environmental factors in the expressions of the traits in okra genotypes and the apparent variation is not only due to the genotypes but also due to the influence of environment. This result supported by Adeoluwa and Kehinde (2011), Nwangburukaet al. (2012), Thirupathiet al. (2012) and Adekoyaet al.(2014) who reported that most of the traits exhibited highly phenotypic variance higher than their respective genotypic variances.

In this study estimate of heritability in broad sense ranged from $28.60 \%$ for fruit weight to $87.96 \%$ for fruits per plant (Table 3). According to Robinson et al. (1955) heritability is categorized as low (0-30\%), moderate (31-60\%) and high $>60 \%$. Accordingly, heritability estimate in broad sense was high $(>60 \%)$ for branches per plant $(63.58 \%)$, picking duration (70.04\%), days to first fruit harvest (71.46\%), fruits per plant (87.96\%) and fruit yield (84.55\%). This result is agreement with Yonas et al. (2014a) who reported high heritability estimates for fruit yield per plant, plant height and number of branches per plant; Akotkar et al. (2010) who reported high broad sense heritability for plant height; Obiadalla-Ali et al. (2013) for days to flowering and Simon et al. (2013b) high heritability for tender fruit yield per plant. If heritability of a character is very high around $80 \%$ or more, selection for such character is fairly easy. This is because there would be a close correspondence between the genotypic and phenotypic variations due to relatively small contribution of the environment to the phenotype expression of the trait (Singh et al., 1990).

Moderate heritability values (31-60\%) were registered for rest of all the traits except fruit weight (28.60). Very low heritability reveals the ineffectiveness of direct selection for the improvement of the traits while moderate heritability suggests improvement through selection. Snowderet al., (2005) had also reported that when the heritability of a trait is medium to high, selection based on the individual level of performance allows relatively rapid rate of improvement

The genetic advance as the percentage of the mean (GAM) at 5\% selection intensity is presented (Table 3). In this study, genetic advance (in \% of mean) ranged between $5.00 \%$ for days to first flowering to $52.08 \%$ for yield (t/ha). Yonaset al., (2014b) also reported genetic advance in the ranged between 5.94\% for number of epicalyxes to $198.15 \%$ for number of primary branches. The observed differences in results of different studies may be due to the different genotypes used in each experiment and the environmental differences where the genotypes were grown.

Genetic advance as percent mean was categorized as high ( $\geq 20 \%)$, moderate (10-20\%) and low (0-10\%) (Johnson et al., 1955). As per this suggestion, the highest $(\geq 20 \%)$ genetic advance was observed for branches per plant, days to first fruit harvest, fruits per plant and yield (t/ha). Akotkaret al., (2010) also reported high genetic advance for plant height and number of fruits per plant. This indicated that these traits are controlled more of by additive genes (Panse, 1957). Moderate genetic advance (10-20\%) was registered for plant height (16.74\%). This result is in agreement with Akotkaret al., (2010) who reported moderate heritability for days to first flowering and fruit diameter. Johnson et al., (1955) suggested that heritability estimates along with genetic advance were more useful in predicting the effect of selecting the best individual. High heritability along with high genetic advance as percent of the mean was obtained for plant height $(97.32 \%$ and $29.98 \%)$, fruits per plant $(88.55 \%$ and $50.44 \%)$, seeds per fruit $(73.02 \%$ and $34.00 \%)$, average fruit weight $(60.51 \%$ and $26.04 \%)$ and fruit yield per plant $(74.99 \%$ and $57.94 \%)$. Consistent result was reported by Haqet al. (2010) for average fruit weight, plant height and fruit yield, Ibrahim (2013) who also reported high heritability and genetic advance for plant height and tender fruit yield,

The phenotypic coefficient of variation (PCV) ranged between $4.18 \%$ (days to first flowering) to $29.90 \%$ (yield in t/ha) while genotypic coefficient of variation (GCV) ranged between 3.19 (days to first flowering) to 27.49\% (yield in t/ha) (Table 3). Similar results were reported by Ibrahimet al.,(2013), Yonaset al.,(2014a) for okra. According to Sivasubramaniah and Meron (1973) PCV and GCV values greater than 20\% are regarded as high, values between $10 \%$ and $20 \%$ to be medium whereas values less than $10 \%$ are considered to be low. Based on this delineation PCV and GCV recorded in this study, picking duration (4.75\% and 3.98\%), days to first flowering (4.18\% and 3.19\%), 
fruit length (9.97\% and 6.63\%), fruit diameter $(6.09 \%$ and $4.58 \%)$ and fruit weight $(9.18 \%$ and $4.91 \%)$ had low values $(<10 \%)$ for both phenotypic and genotypic coefficient of variations.

Daset al.,(2012) reported that low PCV and GCV values for days to first flowering. The low PCV and GCV value of traits suggests the higher influence of environment on these traits thus; selection on the phenotypic basis would not be effective for the genetic improvement (Bharathiveeramaniet al.,2012; Das et al.,2012; Karri and Pinaki 2012; Thirupathiet al.,2012; and Ibrahimet al.,2013).

Moderate GCV and PCV were found in plant height (13.60 and 10.51\%) and days to first fruit harvest (19.50\% and $16.50 \%$ ) (Table 3). Medium PCV and GCV value suggests that these characters are controlled more of by the genetic factors. Hence, these characters amenable to selection for further improvement. This result is in agreement with the finding of Das et al.,(2012), Thirupathiet al.,(2012) and Ibrahimet al.,(2013) who reported medium PCV and GCV values of characters.

Among all characters exhibiting high degree of genotypic and phenotypic coefficients of variation were in number of primary branches per plant $(26.10 \%$ and $20.81 \%)$, fruits per plant $(26.26 \%$ and $24.63 \%)$ and fruit yield $(29.90 \%$ and $27.49 \%$ ), respectively. The closer magnitude of genotypic and phenotypic coefficients of variation indicated that a greater role was played by genotypes rather than environment. The results of the present investigation are agree with Hazra and Basu (2000), Dhallet al.,(2001), Gandhi et al.,(2001), Ravindraet al.,(2004) and Singh and Singh (2006). The results of this study suggests that traits with high PCV and GCV are amenable for selection whereas hardly possible to improve traits contrarily to those traits with low phenotypic and genotypic coefficient of variations. The research findings of Bharathiveeramanet al.,2012, Nwangburukaet al.,2012 and Swati et al.,2014 who suggested that the high phenotypic and genotypic coefficient of variation is an indication of the less influence of environmental factors in the expression of such traits and the higher possibility to improve them through selection breeding. The high PCV and GCV value with low magnitude of differences between the two genetic parameters indicates that the less environmental influence on the phenotypic expression. Hence, selection of desired character uses phenotypic value may be effective in improving the character.

Table 3:- Estimation of statistical and genetic parameters of yield and its contributing characters of different okra genotypes.

\begin{tabular}{|c|c|c|c|c|c|c|c|c|c|c|c|c|}
\hline $\begin{array}{l}\text { Paramet } \\
\text { ers }\end{array}$ & $\begin{array}{l}\text { Mean } \\
\text { Sum } \\
\text { of } \\
\text { squar } \\
\text { e }\end{array}$ & $\begin{array}{c}\text { Mea } \\
\text { n }\end{array}$ & $\begin{array}{l}\text { Rang } \\
\text { e }\end{array}$ & $\begin{array}{c}\text { Genot } \\
\text { ypic } \\
\text { varia } \\
\text { nce }\end{array}$ & $\begin{array}{c}\text { Environ } \\
\text { mental } \\
\text { variance }\end{array}$ & $\begin{array}{l}\text { Phenot } \\
\text { ypic } \\
\text { varianc } \\
\text { e }\end{array}$ & $\begin{array}{c}\text { Heritab } \\
\text { ility }\end{array}$ & $\begin{array}{l}\text { Genet } \\
\text { ic } \\
\text { Adva } \\
\text { nce } \\
(5 \%)\end{array}$ & $\begin{array}{l}\text { Genet } \\
\text { ic } \\
\text { Adva } \\
\text { nce } \\
\text { in } \\
\text { perc } \\
\text { ent } \\
\text { nean }\end{array}$ & $\begin{array}{l}\text { Genoty } \\
\text { pic } \\
\text { Coeffici } \\
\text { ents } \\
\text { of } \\
\text { Variat } \\
\text { ions }\end{array}$ & \begin{tabular}{|l} 
Phenot \\
ypic \\
Coeffici \\
ents \\
of \\
variatio \\
ns
\end{tabular} & $\begin{array}{l}\text { Environ } \\
\text { mental } \\
\text { Coefficie } \\
\text { nts } \\
\text { Of } \\
\text { Variatio } \\
\text { ns }\end{array}$ \\
\hline $\begin{array}{l}\text { Plant } \\
\text { height } \\
(\mathrm{cm})\end{array}$ & $\begin{array}{l}927 . \\
8 * *\end{array}$ & $\begin{array}{l}15 \\
1.1\end{array}$ & $\begin{array}{l}123 \\
.2- \\
174 \\
.5\end{array}$ & $\begin{array}{l}252.5 \\
4\end{array}$ & 170.24 & $\begin{array}{l}422.7 \\
8\end{array}$ & 59.73 & $\begin{array}{l}25.3 \\
0\end{array}$ & $\begin{array}{l}16.7 \\
4\end{array}$ & 10.51 & 13.60 & 8.63 \\
\hline $\begin{array}{l}\text { Branches } \\
\text { per plant }\end{array}$ & $\begin{array}{l}0.58 \\
0\end{array}$ & $\begin{array}{l}1.9 \\
4\end{array}$ & $\begin{array}{l}1.0 \\
0- \\
2.5 \\
0 \\
\end{array}$ & 0.16 & 0.09 & 0.26 & 63.58 & 0.66 & $\begin{array}{l}34.1 \\
8\end{array}$ & 20.81 & 26.10 & 15.75 \\
\hline $\begin{array}{l}\text { Picking } \\
\text { duration }\end{array}$ & $\begin{array}{l}13.8 \\
6^{* *}\end{array}$ & $\begin{array}{l}45 . \\
24\end{array}$ & $\begin{array}{l}42 . \\
67- \\
49 . \\
33\end{array}$ & 3.24 & 1.39 & 4.62 & 70.04 & 3.10 & 6.86 & 3.98 & 4.75 & 2.60 \\
\hline $\begin{array}{l}\text { Days to } \\
\text { first } \\
\text { Flowerin } \\
\mathrm{g}\end{array}$ & $\begin{array}{l}5.21 \\
* *\end{array}$ & $\begin{array}{l}37 . \\
27\end{array}$ & $\begin{array}{l}35 . \\
00- \\
40 . \\
00\end{array}$ & 1.40 & 1.01 & 2.41 & 58.01 & 1.86 & 5.00 & 3.19 & 4.18 & 2.71 \\
\hline Days to & 5.10 & 7.4 & 5.3 & 1.50 & 0.60 & 2.10 & 71.46 & 2.13 & 28.7 & 16.49 & 19.50 & 10.42 \\
\hline
\end{tabular}




\begin{tabular}{|c|c|c|c|c|c|c|c|c|c|c|c|c|}
\hline $\begin{array}{l}\text { first } \\
\text { fruit } \\
\text { harvest }\end{array}$ & $* *$ & 27 & $\begin{array}{l}3- \\
9.3 \\
3\end{array}$ & & & & & & 1 & & & \\
\hline $\begin{array}{l}\text { Fruit } \\
\text { length } \\
(\mathrm{cm})\end{array}$ & 3.81 & $\begin{array}{l}14 . \\
26\end{array}$ & $\begin{array}{l}12 . \\
55- \\
15 . \\
85\end{array}$ & 0.89 & 1.13 & 2.02 & 44.22 & 1.29 & 9.08 & 6.63 & 9.97 & 7.44 \\
\hline $\begin{array}{l}\text { Fruit } \\
\text { diameter } \\
(\mathrm{mm})\end{array}$ & 2.32 & $\begin{array}{l}17 . \\
13\end{array}$ & $\begin{array}{l}15 . \\
57- \\
18 . \\
54\end{array}$ & 0.62 & 0.47 & 1.09 & 56.53 & 1.21 & 7.09 & 4.58 & 6.09 & 4.01 \\
\hline $\begin{array}{l}\text { Fruit } \\
\text { weight } \\
\text { (g) }\end{array}$ & 3.38 & $\begin{array}{l}15 . \\
98\end{array}$ & $\begin{array}{l}13 . \\
96- \\
17 . \\
81\end{array}$ & 0.62 & 1.54 & 2.15 & 28.60 & 0.86 & 5.41 & 4.91 & 9.18 & 7.76 \\
\hline $\begin{array}{l}\text { Fruits } \\
\text { per plant }\end{array}$ & $\begin{array}{l}9.21 \\
* *\end{array}$ & $\begin{array}{l}10 . \\
21\end{array}$ & $\begin{array}{l}6.7 \\
0- \\
15 . \\
27\end{array}$ & 6.33 & 0.87 & 7.19 & 87.96 & 4.86 & $\begin{array}{l}47.5 \\
8\end{array}$ & 24.63 & 26.26 & 9.11 \\
\hline $\begin{array}{l}\text { Yield } \\
(\mathrm{t} / \mathrm{ha})\end{array}$ & $\begin{array}{l}11.2 \\
0^{* *}\end{array}$ & $\begin{array}{l}8.9 \\
58\end{array}$ & $\begin{array}{l}6.0 \\
4- \\
13 . \\
73\end{array}$ & 6.06 & 1.11 & 7.17 & 84.55 & 4.66 & $\begin{array}{l}52.0 \\
8\end{array}$ & 27.49 & 29.90 & 11.75 \\
\hline
\end{tabular}

\section{Conclusion:-}

The ranges of mean values revealed sufficient variation for all the traits under study. The maximum range of variability was observed for plant height $(123.2-174.5 \mathrm{~cm})$ followed by fruits per plant $(6.70-15.27)$ and yield $(6.04-$ $13.73 \mathrm{t} / \mathrm{ha}$ ). For all the characters under study, phenotypic variances were higher than the corresponding genotypic variances. The phenotypic variance was highest for plant height (422.78) followed by fruits per plant and yield. The phenotypic variance was lowest for branches per plant followed by fruit diameter and fruit length. The estimates of heritability in broad sense ranged from $28.60 \%$ for fruit weight to $87.96 \%$ for fruits per plant and high broad sense heritability was for found in branches per plant, picking duration, days to first fruit harvest, fruits per plant and fruit yield. The highest genetic advance was observed for branches per plant, days to first fruit harvest, fruits per plant and yield. The phenotypic coefficient of variation (PCV) ranged between $4.18 \%$ (days to first flowering) to 29.90\% (yield in t/ha) while genotypic coefficient of variation (GCV) ranged between 3.19 (days to first flowering) to $27.49 \%$ (yield in t/ha). The high PCV and GCV value with low magnitude of differences between the two genetic parameters indicates that the less environmental influence on the phenotypic expression. Hence, selection of desired character uses phenotypic value may be effective in improving the character.

\section{Conflict of Interests:}

The authors declare that there is no conflict of interests regarding the publication of this paper

\section{References:-}

1. Patil, P., Sutar, S., Joseph, J. K., Malik, S., Rao, S., Yadav, S., \&Bhat, K. V. (2015). A systematic review of the genus Abelmoschus (Malvaceae). Rheedea, 25(1), 14-30.

2. Hughes, J. (2008, March). Just famine foods? What contributions can underutilized plants make to food security?. In International Symposium on Underutilized Plants for Food Security, Nutrition, Income and Sustainable Development 806 (pp. 39-48).

3. Gemede, H. F., Ratta, N., Haki, G. D., Woldegiorgis, A. Z., \&Bey, F. (2014). Nutritional quality and health benefits of okra (Abelmoschusesculentus): A review. Global Journal of Medical Research.

4. Kumar, S., Parekh, M. J., Fougat, R. S., Patel, S. K., Patel, C. B., Kumar, M., \& Patel, B. R. (2017). Assessment of genetic diversity among okra genotypes using SSR markers. Journal of Plant Biochemistry and Biotechnology, 26(2), 172-178. 
5. Purkait, K., Das, S., Ali, K. A., \&Chakraborty, P. (2016). Phytochemical investigation and hypoglycaemic effect of Abelmoschusesculentus. Research Journal of Pharmacy and Technology, 9(2), 162-164.

6. Petropoulos, S., Fernandes, Â., Barros, L., \& Ferreira, I. C. (2018). Chemical composition, nutritional value and antioxidant properties of Mediterranean okra genotypes in relation to harvest stage. Food chemistry, 242, 466474.

7. Rashid, M. M. (1999). "SabjiBiggan". Rashid Publishing House, Dhaka, 476.

8. Anonymous. (1993). Research and development of vegetables crops. In "Workshop on Importance of Okra as Summer Vegetable". IPSA, Gazipur. 1-7.

9. Düzyaman, E., \&Vural, H. (2001, November). Evaluation of pod characteristics and nutritive value of okra genetic resources. In International Symposium on Sustainable Use of Plant Biodiversity to Promote New Opportunities for Horticultural Production 598 (pp. 103-110).

10. Ahmad, A. N. E. E. S., \&Saleem, M. U. H. A. M. M. A. D. (2003). Combining ability analysis in Zea mays L. Int J AgricBiol, 5, 239-244.

11. Khodambashi, M., Bitaraf, N., \&Houshmand, S. (2012). Generation mean analysis for grain yield and its related traits in lentil.

12. Menkir, A. (2008). Genetic variation for grain mineral content in tropical-adapted maize inbred lines. Food chemistry, 110(2), 454-464.

13. Jayasudha, S., \& Sharma, D. (2010). Genetic parameters of variability, correlation and path-coefficient for grain yield and physiological traits in rice (Oryza sativa L.) under shallow lowland situation. Electronic Journal of Plant Breeding, 1(5), 1332-1338.

14. Sadek, S.E., Ahmed, M.A., Abd El-Ghaney, H.M. (2006). Correlation and path coefficient analysis in five parents inbred lines and their six white maize (Zea mays L.) single crosses developed and grown in Egypt. J. Applied Sci. Res., 2:159-167.

15. Anonymous.( 1989). A Annual Weather Report, IPSA. Meteorological Station, IPSA, Salna, Gazipur.

16. Rashid, M.M., (1999.) "ShabjeeBiggan" (in Bengali) Bangla Academy.Dhaka. Bangladesh.

17. Panse, V. G., \&Sukhatme, P. V. (1954). Statistical methods for agricultural workers. Statistical methods for agricultural workers.

18. Snedecor, G. W., \& Cochran, C. W. G., (1967). Statistical methods. The Iowa State University Press, IOWA, U.S.A.

19. Johnson, H. W., Robinson, H. F., \& Comstock, R. E. (1955). Genotypic and phenotypic correlations in soybeans and their implications in selection 1. Agronomy journal, 47(10), 477-483.

20. Burton, G.W., (1953). Quantitative inheritance in grasses. Proc. Sixth Int. Grassl. Congr. 1: 277-283.

21. Sivasubramanian, S. \&MadhavaMenon, P., (1973). Genotypic and phenotypic variability in rice. Madras Agric. J. 60(9-13): 1093-1096.

22. Lush, J. L. (1940). Intra-sire correlations or regressions of offspring on dam as a method of estimating heritability of characteristics. Journal of animal science, 1940(1), 293-301.

23. Mehta, D.R., Dhaduk, L.K. \& Patel, K.D. (2006). Genetic variability, correlation and path analysis studies in okra [Abelmoschusesculentus (L.) Moench]. Agri. Sci. Digest. 26 (1): 15-18.

24. Akotkar, P. K., De, D. K., \& Pal, A. K. (2010). Genetic variability and diversity in okra (Abelmoschusesculentus L. Moench). Electronic Journal of Plant Breeding, 1(4), 393-398.

25. Ibrahim, E. A. A., Abed, M. Y., \&Moghazy, A. M. (2013). Genetic behavior of families selected from some local okra (Abelmoschusesculentus L. Moench) populations in Egypt. Plant Breeding and Biotechnology, 1(4), 396-405.

26. AdeOluwa, O. O., \&Kehinde, O. B. (2011). Genetic variability studies in West African okra (Abelmoschuscaillei). Agri. Biol. JN Am, 2(10), 1326-1335.

27. Nwangburuka, C. C., Denton, O. A., Kehinde, O. B., Ojo, D. K., \&Popoola, A. R. (2012). Genetic variability and heritability in cultivated okra [Abelmoschusesculentus(L.) Moench]. Spanish journal of agricultural research, (1), 123-129.

28. Thirupathi Reddy, M., HariBabu, K., Ganesh, M., Chandrasekhar Reddy, K., Begum, H., Purushothama Reddy, B., \&Narshimulu, G. (2012). Genetic variability analysis for the selection of elite genotypes based on pod yield and quality from the germplasm of okra (Abelmoschusesculentus L. Moench). Journal of Agricultural Technology, 8(2), 639-655.

29. Adekoya, M. A., Ariyo, O. J., Kehinde, O. B., \&Adegbite, A. E. (2014). Correlation and Path Analyses of Seed Yield in Okra (Abelmoschusesculentus (L.) Moench) Grown Under Different Cropping Seasons. Pertanika Journal of Tropical Agricultural Science, 37(1). 
30. Robinson, H. F., Comstock, R. E., \& Harvey, P. H. (1949). Estimates of heritability and the degree of dominance in corn. Agronomy journal, 41(8), 353-359.

31. Yonas, M., Garedew, W., \&Debela, A. (2014). Multivariate analysis among okra (Abelmoschusesculentus (1.) moench) collection in South Western Ethiopia. Journal of Plant Sciences, 9(2), 43-50.

32. Akotkar, P. K., De, D. K., \& Pal, A. K. (2010). Genetic variability and diversity in okra (Abelmoschusesculentus L. Moench). Electronic Journal of Plant Breeding, 1(4), 393-398.

33. Obiadalla-Ali, H. A., Eldekashy, M. H. Z., \&Helaly, A. A. (2013). Combining ability and heterosis studies for yield and its components in some cultivars of okra (Abelmoschusesculentus L. Moench). American-Eurasian J Agric Environ Sci, 13, 162-167.

34. Singh, B.D. (1990). Plant Breeding. Kalyani Publishers, New Delhi, India. 702.

35. Snowder, G. D., Cushman, R. A., Allan, M., Thallman, R., \&Echternkamp, S. (2005, January). Heritability estimate for bilateral ovulation in heifers. In American Society of Animal Science (Vol. 83, No. 2, pp. 39-42).

36. Yonas, M., Garedew, W., \&Debela, A. (2014b). Variability and association of quantitative characters among okra [Abelmoschusesculentus (L.) Moench] collection in south western Ethiopia. J. Biol. Sci, 14(5), 336-342.

37. Johnson, H. W., Robinson, H. F., \& Comstock, R. E. (1955). Genotypic and phenotypic correlations in soybeans and their implications in selection 1. Agronomy journal, 47(10), 477-483.

38. Panse, V.G. (1957). Genetics of quantitative character in relation to plant breeding. Indian J. Genet.17 (3):1728.

39. Haq, I. U. (2009). Genetic basis of variation for salinity tolerance in okra (Abelmoschusesculentus L.) (Doctoral dissertation, University of Agriculture Faisalabad Pakistan).

40. Das, S., Chattopadhyay, A., Chattopadhyay, S. B., Dutta, S., \&Hazra, P. (2012). Genetic parameters and path analysis of yield and its components in okra at different sowing dates in the Gangetic plains of eastern India. African Journal of Biotechnology, 11(95), 16132-16141.

41. Bharathiveeramani, B., Prakash, M., \&Seetharam, A. (2012). Variability studies of quantitative characters in Maize (Zea mays L.). Electronic Journal of Plant Breeding, 3(4), 995-997.

42. Das, S., Chattopadhyay, A., Chattopadhyay, S. B., Dutta, S., \&Hazra, P. (2012). Genetic parameters and path analysis of yield and its components in okra at different sowing dates in the Gangetic plains of eastern India. African Journal of Biotechnology, 11(95), 16132-16141.

43. Karri, S. R., \&Acharyya, P. (2012). Performance of okra [Abelmoschusesculentus (L.) Moench] cultivars under summer and rainy environments. International Journal of Advance life Science, 2, 16-26.

44. Hazra, P., \&Basu, D. (2000). Genetic variability, correlation and path analysis in okra. Annals of Agricultural Research, 21(3), 452-453.

45. Dhall, R.K., Arora, S.K. \&Mamta R. (2001). Studies on variability, heritability and genetic advance of generations in okra (Abelmoschusesculentus L. Moench). Haryana J. Hortic. Sci.30 (1 \& 2): 76-78.

46. Gandhi, H.T., Yadav, M.D. \&Navale, P.A. (2001). Studies on variability in okra (Abelmoschusesculentus L. Moench). J. Maharashtra agric. Univ.26 (2): 146-148.

47. Ravindra, M., Jaiprakashnarayan, R.P. \&Madalageri, M.B. (2004). Studies on genetic variability for fruit and yield parameters in okra [Abelmoschusesculentus (L.) Moench]. Karnataka J. Hort. 1(1): 1-5

48. Singh, S.P., \& Singh, J.P., (2006). Variability, heritability and scope of improvement for yield components in okra [Abelmoschusesculentus (L.) Moench]. Intl. J. Plant Sci. 1(2): 154-155.

49. Bharathiveeramani, B., Prakash, M., \&Seetharam, A. (2012). Variability studies of quantitative characters in Maize (Zea mays L.). Electronic Journal of Plant Breeding, 3(4), 995-997.

50. Nwangburuka, C. C., Denton, O. A., Kehinde, O. B., Ojo, D. K., \&Popoola, A. R. (2012). Genetic variability and heritability in cultivated okra [" Abelmoschusesculentus"(L.) Moench]. Spanish journal of agricultural research, (1), 123-129.

51. Swati, B., Reena, N., Meenakshi, R. \& Jain, P. K. (2014). Genetic variability in Okra [Abelmoschusesculentus (L.). Moench]. An Intl. Quarterly J. Environ. Sci.6: 153-156. 